\title{
THE DEATH OF A YOUNG SON IN VIOLENT CIRCUMSTANCE: UNDERSTANDING THE EXPERIENCE OF THE MOTHER
}

\author{
Ana Carolina Jacinto Alarcão ${ }^{1}$ \\ Maria Dalva de Barros Carvalho \\ Sandra Marisa Pelloso 2
}

Alarcão ACJ, Carvalho MDB, Pelloso SM. The death of a young son in violent circumstance: understanding the experience of the mother. Rev Latino-am Enfermagem 2008 maio-junho; 16(3):341-7.

This study was aimed at understanding the life of a mother who lost their child in violent circumstances. The methodological proceedings were supported on phenomenology. The study population was constituted by five mothers who had lost its young children for homicide. These homicides occurred different times ranging from 50 days to 10 years. I used as instrument of collection of data open interview the phenomenological method guided by a orienting question. The analysis phenomenology in their discourses showed the comprehension of essential meanings which were systematized in categories: the child's mummification in the memory; the two ways followed by the publicity concerning the death; fondness to spirituality to endure the pain from the child's death; maternal complicity and impunity. The results of this study can contribute to elaboration of intervention proposals close to the mothers in the sense of helping them in the reorganization of their lives after son's death.

DESCRIPTORS: death; violence; mothers

\section{LA MUERTE DE UN HIJO JOVEN EN CIRCUNSTANCIAS VIOLENTAS: COMPRENDIENDO LA VIVENCIA DE LA MADRE}

Este trabajo tuvo como objetivo comprender la vivencia de la madre delante de la pérdida de un hijo joven en circunstancias violentas. El procedimiento metodológico fue guiado por la fenomenología. La población del estudio fue constituida por cinco madres que perdieron sus hijos jóvenes por homicidio. Esos homicidios ocurrieron en distintos intervalos de tiempo, entre 50 días y 10 años. Utilizamos como instrumento de recolección de datos la entrevista abierta del método fenomenológico dirigida por una pregunta orientadora. El análisis fenomenológico de los discursos reveló la comprensión de los significados esenciales sistematizados en las categorías: momificando el hijo en la memoria; los caminos recorridos por la publicidad frente a la muerte; apego a la espiritualidad para soportar el dolor de la muerte de un hijo; complicidad materna; e impunidad de los asesinos. Los resultados de este estudio pueden contribuir para elaborar propuestas de intervención junto a las madres para ayudarlas a reconstruir sus vidas después de la muerte de un hijo.

DESCRIPTORES: muerte; violencia; madres

\section{A MORTE DE UM FILHO JOVEM EM CIRCUNSTÂNCIA VIOLENTA: COMPREENDENDO A VIVÊNCIA DA MÃE}

Este trabalho teve como objetivo compreender a vivência da mãe na perda de um filho jovem em circunstâncias violentas. O procedimento metodológico foi apoiado na fenomenologia. A população de estudo foi constituída por cinco mães que perderam seus filhos jovens por homicídio. Esses homicídios aconteceram em épocas distintas, com intervalo de tempo entre 50 dias e 10 anos. Utilizou-se como instrumento de coleta de dados a entrevista aberta do método fenomenológico, norteado por uma questão orientadora. A análise fenomenológica dos discursos desvelou a compreensão das significações essenciais sistematizadas nas categorias: mumificação do filho na memória; dois caminhos trilhados pela publicidade frente à morte; apego à espiritualidade para suportar a dor da morte de um filho; cumplicidade materna e impunidade dos assassinos. Os resultados deste estudo podem contribuir para a elaboração de propostas de intervenção junto às mães no sentido de ajudá-las na reorganização de suas vidas após a morte de um filho.

DESCRITORES: morte; violência; mães

${ }^{1}$ Psychologist, M.Sc., Maringá State University, Brazil, e-mail: anacarolina.78@hotmail.com; ${ }^{2}$ Ph.D. in Nursing, Faculty, Maringá State University, Brazil, email: mdbcarvalho@terra.com.br, sspelloso@uem.br 


\section{INTRODUCTION}

Nowadays, violence has gained space and has grown in a scary way. The increase in the number of young people killed by homicide is more and more alarming. In 1996, the World Health Organization (WHO) considered it as an important public health issue $^{(1)}$.

The interest in performing this research appeared mainly out of my interaction with the mothers of young people murdered in my professional practice, as a psychologist acting in public policies for young people in social vulnerability conditions. In this context, the mother's suffering was always evident, with feelings of injustice, frustration and revolt that accompany them for a long time.

This has urged me to reflect on this topic, little explored and involved by feelings of pain, bringing the need to understandg the experience of mothers who lost their children murdered, to be able, as a professional, to aid them authentically in a more human and efficient way, and act with interventions that may help them to cope with pain.

The death of a young person is interpreted as an interruption of their biological cycle and this provokes feelings of impotence, frustration, sadness, pain, suffering and anguish. It is known that death is an inevitable fact. Hhowever, it is difficult to accept when it happens prematurely. Coping with death is a difficult issue, even worse when it happen to a child. This is because the death of a young person is a situation that is not naturally though of by the family, as it would be normal for the parents to die first in a lifecycle perspective ${ }^{(2)}$.

If death occurs in a sudden and unexpected way, the mother's feeling of irreparable loss can worsen, leading to non-acceptation, disorganization and the mother's impotence ${ }^{(3)}$.

The feelings experienced by mothers who lost their children by homicide feed the search for justice and punishment for the guilty, the drive to understand what happened and the need to express the pain and talk about the tragedy, which can characterize a possible risk factor for the development of complicated grieving $^{(4)}$

Having these considerations as premises, this paper aimed at understanding the mother's experience when losing a young child under violent circumstances.

\section{METHODOLOGY}

The option for phenomenology matched the concern related to the experience phenomenon of mothers of young people who were murdered. For this phenomenon to make sense and be intelligible, it was necessary to discover what it means for those who have experienced it. Phenomenology has shown to be the ideal method, as it states that what serves as a base for all sciences is the return to the experience world, the experienced world ${ }^{(5)}$.

As a philosophical movement, phenomenology became one of the main streams of thought in the twentieth century, based on Edmund Husserl's (1859-1938) conceptions, which proposed, through phenomenology, the "return to the things themselves", the essence analysis, understood as ideal units of meaning, elements that composed the meaning of our experience. Phenomenology has the goal of direct observation and description of phenomena that are experienced by conscience, without theories about the causal explanations and as prejudice-free as possible ${ }^{(6)}$.

This study was carried out in a medium-sized city located in the northwest of Paraná State, Brazil. According to the Institute of Economic and Social Development from Paraná - IPARDES ${ }^{(7)}$, the referred city shows the second highest rate of population growth in the state. However, this growth happened in an unorganized and unplanned way, which led to several social and economic problems, such as several forms of violence, resulting in teenage deaths.

From the contact performed with the judiciary and police station, I obtained the information of an average of seven teenage homicides a year. This annual average was the reference for the number of mothers of murdered young people to be interviewed.

With access to the police files at the police station and to some lawsuits at the judiciary, I randomly selected mothers who had lost their children in the past ten years, to be contacted and invited to participate in the interview. The mothers were chosen from different years, so as to understand the experience and unveil the short and long term feelings caused by the loss of a child by homicide.

Of the seven mothers chosen, I interviewed five because their discourse began to show points in common and new data stopped appearing. Thus, the interviews were finished because the data considered in their convergence and divergence proved to be 
enough to understand the phenomenon ${ }^{(8)}$. The study population consisted of the five mothers of murdered young people.

For data collection, we used the open interview according to the phenomenology method, guided by an orientation question: "what does it mean for you to experience the loss of a child by homicide?". The phenomenology interview is not based on ideas focused on certain goals, since the goal is not to find out about a subject, but about that subject's knowledge ${ }^{(9)}$.

The interviews were performed without time limit, at the mothers' homes, where they talked freely. They were recorded so that the discourse, revealing experience and its singularity and subjectivity, could be heard clearly.

Anonymity and informed consent was guaranteed for all participants. In the content analysis, the mothers were identified by Arabic numbers.

A support and counselling service was designed at the Applied Psychology Unit - APU of Maringá State University, to be consulted by people who required help due to the participation in the research.

Discourse analysis of the murdered young people's mothers went through the four moments described by Giorgi ${ }^{(10)}$, in the search for convergence and also divergence between all meaning units in the interviews, aiming at classifying the phenomenon, which is viable through the subjects' statements. Subjects perceive the facts from their perspectives and this enables the investigator to have several approaches to the phenomenon. The several approaches in the intersubjective crossing reveal common meanings that allow an understanding of the phenomenon, its essence.

The research project was approved by the Permanent Ethics Committee in Research Involving Human Beings - PECR, of Maringa State University, PR, authorization No 373/2005 of

\section{RESULTS}

The five mothers who participated in the research came from families with low socioeconomic background, living on the outskirts of cities - needy of facilities and basic services.

In the first contact with the mothers for the interview about the experience of death of a child in a violent way, they appeared to be nice and receptive, and all of them appeared to be willing to be interviewed, which could mean the possibility to keep on talking about their murdered children.
The mothers' discourse, once transcribed and analyzed, began to show convergence. It is at this moment, when the repetitions, the convergence, begin, that the essential meanings and, thus, the essence of the phenomenon, can be apprehended ${ }^{(8)}$.

The interviewed mothers, no matter the time elapsed since the occurrence of their young children's homicide - which varied from 50 days to ten years went through the experience of loss with similar features, revealed in the categories shown: mummifying the child in memory; death and publicity: tracing two ways; enduring the child's death: attachment to spirituality; mother complicity: mothers of children murderers and mothers of murdered children and justice $x$ impunity.

\section{DISCUSSION}

Mummifying the child in memory

The loss of a child proves to be an intense and complex suffering, due to the fact that the intensity of symptoms and the duration of the parental grief process often differ from the grief process due to other types of loss.

For the mothers, the feelings and the suffering caused by the circumstance of children's death are preserved and relived with each memory. Even if it occurred a long time ago, each of them reported minutely each detail of what happened to their child and described the sequence of facts, remembering times, clothes, statements and the child's wishes before dying.

The mothers' reports revealed the persistent love bond established with the child who died, generates high levels of anguish ${ }^{(12)}$.

Another complicating factor in the experience of a child's loss by murder is the physical violence against their body, which aroused revolt and despair in the mothers.

In the present study, the homicides occurred due to asphyxia, firearms, knives and victim assault (rape), violent deaths that remain in the memory of each mother as an "unworthy death", increasing the pain at each moment and making them imagine the instant of their child's suffering and crying for help.

The deceased person's status can have a strong influence on how they are remembered. The mothers' discourse revealed that these memories are unbearable. 
Despite not accepting their children's death, the mothers did not show attachment to objects and belongings, or denial of the children's death; however, their memories are intense and extensive, which are relived intensively, no matter how much time had elapsed.

This has caused me to believe in a mummification of the mothers' memory, which makes mothers despair and leads to an unsustainable situation, but also means the living preservation of a healthy bond with the child. This memory mummification seems to be a return of the child to the mother's womb, for protection and privacy of so noble and delicate feelings. This mummification does not seem to deny death or the hope of return of the murdered child, but demonstrates a profound affective bond and desire for justice.

The reactions of pain and intense suffering, the mummification of the mother's memories of the child death, revealed that the families struck by violence are not having proper assistance, do not have the necessary support to endure that tragedy, which may negatively influence their personal, family and social life.

Death and publicity: tracing two ways

The media, in its diverse forms, broadcast to the population facts of interest or that cause impact. In news broadcasts, violence is among the most common subjects, due to its growing and increasing rates.

In this information system, there is an evident media invasion, which transforms the loss into public death, leading to the dehumanization of death and the banalization of suffering.

When editing, the media choose the events, the deaths that deserve "investments", that will result in high ratings and reading. Therefore, they invade the event scenes, search family reports and, thus, certainly risk crossing the line of good sense and respect.

Obviously, the mothers reject and oppose the reporters and their child's death. They report the situation of discomfort they were put in by the sensationalist press, which invaded their privacy only in search of news and ratings.

Both the press covering problems and the lack of sensitivity that permeates moments of tragedy are evident. The line beween the duty of informing about a tragedy and respect for the rights of those who want to suffer away from the lenses and microphones is thin and demands great respect and sensitivity from the journalists.

But the massification of these communication means has deepened the trend of transforming tragic deaths into news, and almost simultaneously points towards the banalization of death. This way, death becomes public, impersonal, losing its existential feature as the most irremediable of all possibilities ${ }^{(13)}$.

These practices that invade and expose the pain, mainly of poor and anonymous people, are common in newspapers and broadcasting corporations known as popular, which sell more as a result of the announced tragedies ${ }^{(14)}$.

Nevertheless, the treatment given to the news and the media's attitude towards the victims and their families depend on the institution's profile. The media often reveal a positive function when spreading information, which makes it necessary to understand their role from another standpoint.

As an essential element in our society, the media also act as a denouncing agent, and equally as a memory-fixing agent, when telling and producing a story for society and propagating information, being able to intensify the resolution of cases.

Only for mother No 2, the role of the media was extremely important to solve the case because, after the disappointment in justice regarding the murderer's condemnation, the mother saw the press as an ally. The press, in this case, provided her with the safety and trustworthiness that should be expressed by the judiciary power.

Confidently, mother No 2 stated: ... all the press was good and we have to value the press because something only happens in justice involving the poor if the press is there, to pressure, to put on air.

With these situations experienced by the mothers regarding the media and the publicity around their children's violent death, one may understand the existence of two ways traced by communication means when broadcasting homicides, ways that are opposite and entail different consequences: the media can prove to be a privacy invader and, from another perspective, an ally in search of justice and, indirectly, in the understanding of mother's painful loss.

Enduring the death of a child: attachment to spirituality

The process of experiencing a loss refers to the conceptions mothers have of the world, because the loss can evidence, initially, several beliefs and challenge fundamental values in the search to understand the violent death of a child. 
A non-natural death makes the feelings of incomprehension, injustice and revolt increase. Loss becomes unacceptable, it takes away the children's right to live, differently from when death happens by the natural aging process or disease. When it occurs due to human cruelty, it is inadmissible and the mothers do not resign.

The mother's indignation, revolt and inconformism find shelter in spirituality, in the belief in a world better than the physical world they are shown - a world of violence, disrespect, pain and suffering. Also, which other resources do they have if not the search for the sacred? ${ }^{(15)}$

The mothers, from the start, pointed out the belief in God as a fortress to survive the violent death of a child.

Mother No. 1 reported: She who does not believe in God goes crazy. I sticked to God, otherwise I would not survive... I always go to church, and if someone asks me how I can survive, it is for Him, only God gives us strength, He empowers me.

The intrinsic relation between religion and critical or stressing life periods is clear. Difficulties, suffering and conflicts represent the focus of attention in religious orientations on how to deal with pain, loss, failure, or feelings of impotence before the problems.

Such considerations were revealed in all the interviews: pain, religion, divine power - according to the mothers - end up making the unbearable bearable, when they offer power to deal with the tragedy and keep on living.

This aspect of the restructuring process of life after the death of a child represents a challenge and shows the need for professional reflection on the often neglected or avoided relation between spirituality and loss-facing.

Mother complicity: mothers of children murderers and mothers of murdered children

Motherhood crosses the daily life of women since childhood. From a young age, girls plays with dolls, houses, occupying the role of mother; and the description of this role in childhood also contains the definition of motherhood as caregiving and responsible for family well-being ${ }^{(15)}$.

This motherhood symbolism unifies women as the only ones to experience gestation, birth and breastfeeding, also creating an emotional level of mothers' exclusive understanding in these situations.
All interviewed mothers stated that the experience of motherhood and tragedy, namely a scattered motherhood, generates solidarity and strong alliance among them. Mother No. 2, crying, reported: .... each death that happens, I relive my pain, I think mainly of the mothers who are going through this.

Yet, when losing a child by homicide, directly involving two situations - the victim's and the murderer's - it is interesting to point out that this solidarity among mothers is based on the symbolic representation of maternal love, in which the victim's mother exposes feelings of solidarity and support to the murderer's mother.

All interviewed mothers were concerned in the search for justice and condemnation of the murderers; however, they would refer to the nurderers' mothers with compassion. Mother No. 5 revealed: I think this murderer's mother is against what he does, no mother brings up a son to be a murderer.

Thus, there are two conditions in the loss of a child: the first is the mother in the position of losing a son, suddenly murdered; and the second is the mother in the position of losing a son to the crime world. This "brotherhood" of feelings was acclaimed by all mothers.

Thus, in the discourse of mothers who lost their children by murder, all of them ended up being accomplices and solidary, even towards those mothers. This would be logically impossible: the mothers of the murderers of their children. The mothers of the victims recognized that the other mothers are suffering too, had lost their child, and never wished vengeance, but the murderer's punishment.

Justice $\mathrm{X}$ Impunity

For those whose beloved one was a homicide victim, maintaining the grief is hard, if not impossible, until the legal aspects of the case are solved ${ }^{(16)}$.

With the reality of violence becoming part of our lives and with the cruel experience of impunity, the mothers reveal the construction of a new representation: mothers who seek justice, mothers who appear on the streets, mother who invade public institutions, because of a harsh reality they suffer: violence against their children.

The history of mother No. 2 history illustrated this reality, describing all moments in search of her child's murderer: ... the murderer was a runaway for two and a half years and, during these two years, I looked for him... we had to find him, we never gave up. 
It should be taken into account that these families, besides their children's death and the murderer's impunity, bring the experience of other multiple violence situations, in a context of institutional, social, economic violence, since they are faced with justice-related situations, such as unaccessibility to authorities and information about the resolution of crimes.

Pain becomes an eternally present reality in the life of mothers, and this pain versus love gives rise to power, which will make the justice mother appear. Mother No. 3 showed obstinacy: we mothers never give up.

The hope of meeting their child again does not exist any longer for these mothers. However, the struggle remains, for other children, other mothers' children, so that "this will not happen again". This search for punishment, for doing justice, ends up being a motivator, an incentive to life.

With motherhood, mothers incorporate the function of protecting, caring and guaranteeing physical, emotional and social well-being of their children. The loss of a child represents, for them, failure in the maternal function, and they feel stolen in their role of protecting and being necessary to something or someone. The murder of the child entails guilt, due to the belief that they failed to protecting, making them feel responsible for what happened, for having failed in their care duty ${ }^{(11)}$.

Thus, the wish for justice is indispensable for them. When there is punishment of the murderer, great part of this feeling appears to disappear, as the mothers can verify and say that the guilty ones were punished. Condemnation, therefore, is also a form of diminishing the guilt they feel about the event.

In the interviews, the disadvantages of the mothers in the present study, due to the fact that they lacked wealth, were categorically demonstrated in their access to justice.

\section{REFERENCES}

1. Gawryszewski VP, Kahn T, Mello Jorge MHP. Informações sobre homicídios e sua integração com o setor saúde e segurança pública. Rev Saúde Pública. 2005;39(4):627-33. 2. Poles K, Bousso RS. Compartilhando o processo de morte com a família: a experiência da enfermeira na UTI pediátrica. Rev Latino-am Enfermagem [periódico na Internet]. 2006 Abr [citado 2008 Jan 08];14(2): 207-213. Disponível em: http://www.scielo.br/scielo.php?script=sci arttext\&pid=S01043. Kóvacs MJ. Morte e desenvolvimento humano. São Paulo: Casa do Psicólogo; 1992.
Some tragedies do not choose social classes, but the status does count when it comes to reinvindicating and guaranteeing rights. There is an evident proof that justice is not a synonym of law ${ }^{(14)}$.

With an anguishing cry, mother No. 4 revealed that the murderers ran away, but it is always like that, if the rich had lost a child, then they (the police officers) would run after, but with us, it is like that, it is the same as if they had killed a dog on the street.

However, even in this context, the suffering mothers responsible for their children, without their rights, still insist on converting pain into action, seeking to do justice. The impunity of the murderers revealed to be a negative influence on the acceptance of a child's loss and on the elaboration by the mothers.

\section{CONCLUDING REMARKS}

We can say that the research and discussions about death have a trajectory of success and advances, but also a horizon filled with challenges, all the more when one considers a support network in diverse areas - health, social, safety, judicial - for those who experience losses. The pain of loss should be cared for and shared by this social network, which should also ensure protection and effective safety for society.

The understanding of experiences of mothers who lost their children in a violent way collaborates for a more understanding view on loss, enabling the confrontation of death with dignity and support. It creates the perspective of more appropriate professional interventions, in which the mothers are heard and cared for. Interventions capable of helping them overcome pain, express their feeling and reinvest in their lives and wishes. Yet, it demonstrates the need for public policies for youth and safety for society.

4. Parkes CM. Luto: Estudos sobre a perda na vida adulta. São Paulo: $\quad$ Summus; 1998 5. Martins J, Boemer MR, Ferraz CA. A fenomenologia como alternativa metodológica para pesquisa - algumas considerações. São Paulo: Maraes/EDUC; 1990.

6. Merighi MAB, Gonçalves R, Ferreira FC. Estudo bibliométrico sobre dissertações e teses em enfermagem com abordagem fenomenológica: tendência e perspectivas. Rev Latino-am Enfermagem [periódico na Internet]. 2007 Ago [citado 2008 Jan 08];15(4): 645-650.Disponível em: http://www.scielo.br/ scielo.php?script=sci_arttext\&pid $=$ S0104- 
7. IPARDES. Secretaria do Estado e do Planejamento e Coordenação Geral [homepage na internet] Curitiba: Instituto Paranaense de Desenvolvimento Econômico e Social [acesso em 2006 fev 02]. Disponível em: http://www.ipardes.pr.gov.br 8. Boemer MR. A fenomenologia na pesquisa em enfermagem. In: Seminário Nacional de Pesquisa em Enfermagem, São Paulo: ABEN/FINEP; 1985.

9. Carvalho MDB. Sendo-com-o-aluno-no-mundo-daenfermagem: a morte no cotidiano do hospital [Doutorado] São Paulo: Escola de Enfermagem de Ribeirão Preto, USP; 1999.

10. Giorgi A. Sketch of a psychological phenomenological method. In: Phenomenology and psychological research. Pittsburg: Duquesne University Press; 1985.

11. Casellato G. Luto pela perda de um filho: a recuperação possível diante do pior tipo de perda. In: Franco MHP. Uma jornada sobre o luto. Campinas: Livro Pleno; 2002.

12. Bowlby J. Formação e rompimentos dos laços afetivos. São Paulo: Martins Fontes; 1997.

13. Heidegger M. Ser e tempo. v.2. Rio de Janeiro: Vozes; 1993.

14. Biancharelli A. A morte vista da redação: como os jornalistas lidam com a morte. In: Franco MHP. Uma jornada sobre o luto. Campinas (SP): Livro Pleno; 2002.

15. Gimenez MGG. Espiritualidade e luto. In: Franco MHP. Uma jornada sobre o luto. Campinas: Livro Pleno; 2002.

16. Worden JW. Terapia do luto: um manual para o profissional de saúde mental. 2. ed. Porto Alegre: Artes Médicas; 1998. 